\title{
Humanitarian Logistics: Challenges for Human Resource Management
}

\author{
Yamini Meduri \\ Vignana Jyothi Institute of Management,Vignana Jyothi Nagar, Bachupally,Kukatpally (via), Hyderabad-500090, India \\ Corresponding Author: yamini.meduri@vjim.edu.in
}

\begin{abstract}
Exponentially increased number of disasters and continuous failure of humanitarian aid lead to increase in attention towards humanitarian logistics. This paper aims at understanding the conceptual framework of humanitarian logistics with a special focus on the human resources involved in the disaster relief operations. The study used a conceptual research methodology through an extensive literature review from both academic and practitioner journals. The study attempts to identify the challenges for planning and managing human resources for a humanitarian-aid organization considering the uncertainty of disaster location and intensity. The study also tried to indicate the scope for further research in the area. The paper is conceptual in nature and empirical research is required to validate the findings. The study sets an agenda for academic research. The findings of the study will help the academia to establish a framework for studying the humanitarian organizations which are different from the general business organizations. The study also provides a tool for the practitioners to understand the challenges, plan, hire and retain the human resources accordingly. Research focus from academia in the area of humanitarian logistics is less compared to practitioner's research. Also, not much research concentrated on the human resources aspect of disaster management which is different when compared to the business organizations.
\end{abstract}

Keywords Humanitarian Logistics, Disaster Management, Emergency Services, Human Resources, Demand-Supply of Labor

\section{Introduction}

On 16 June 2013, when half the world just woke up for a new day, not knowing what was happening in
Uttarakhand,where thousands were waiting for once in a lifetime pilgrimage at Kedarnath, one of the holy shrines in India.At Kedarnath, another day with pilgrims started and in no time, Holy Ganges shook life disastrously. The cloud burst resulted in a massive destruction of life. As Indian Meteorological Department (IMD) in 2010 explained "cloud burst", occurs when a cloud empties out its water content at speeds of over $10 \mathrm{~cm}$ per hour for more than an hour at one place and in Uttarakhand the total rainfall was $261 \mathrm{~cm}$ in three days. It took almost 15 days for the armed forces to rescue the people affected by the disaster while the Government announced that it might take 3years to reopen the holy shrine for pilgrims. However, there are no official reports from the Government of India discussing the same.

According to the Disaster Management Act, 2005 of India, 'Disaster Management means a continuous and integrated process of planning, organizing, coordinating and implementing measures which are necessary or expedient for:

1. Prevention of danger or threat of any disaster

2. Mitigation or reduction of risk of any disaster or its severity or consequences

3. Capacity-building

4. Preparedness to deal with any disaster

5. Prompt response to any threatening disaster situation or disaster

6. Assessing the severity or magnitude of effects of any disaster

7. Evacuation, Rescue and Relief

8. Rehabilitation and reconstruction

There is a general agreement that the world is increasingly experiencing the frequency and severity of natural and man-made disasters (Roh et. al, 2008) over the few years (Fig. 1). Though, the numbers of people who are killed because of disasters has come down (Fig. 2), the numbers affected has exponentially gone up (Fig. 3). Considering the high cost of restoration, it is important that a proactive action is taken to reduce the impact (Veen, 2004; Alexandar, 2005). 
Natural disasters reported $1900-2011$

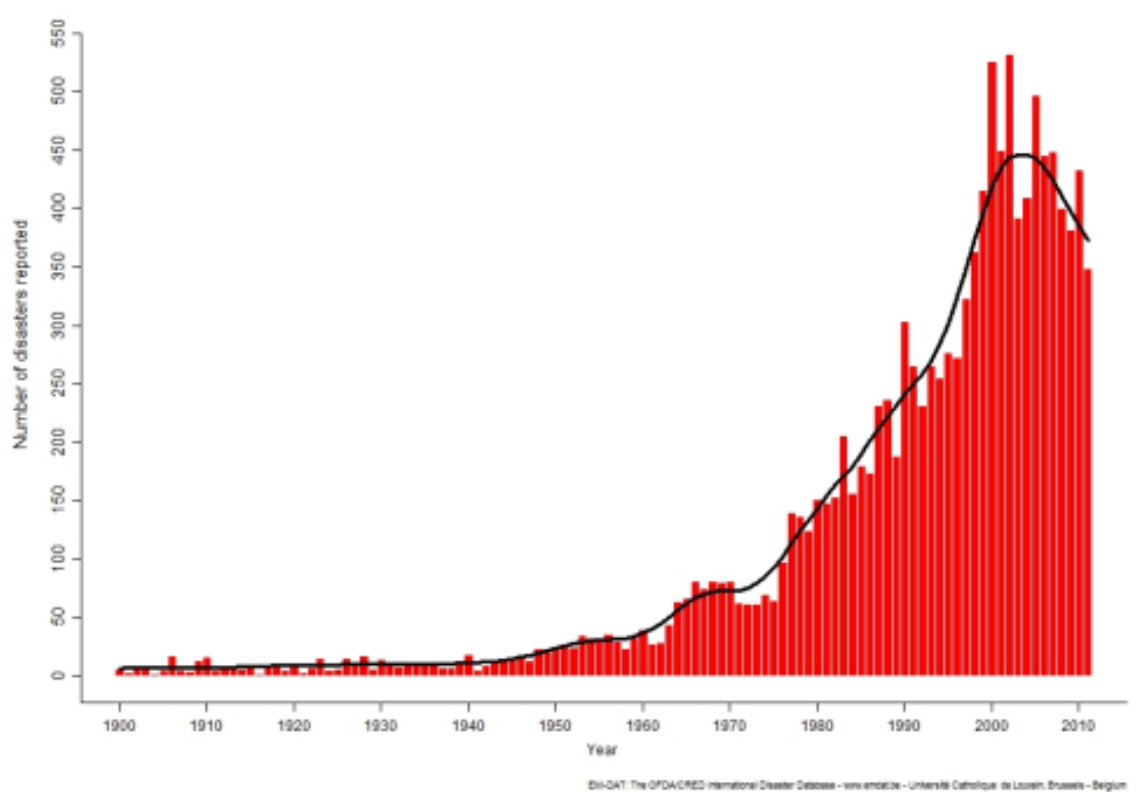

Figure 1. No. of Disasters Reported 1900-2011

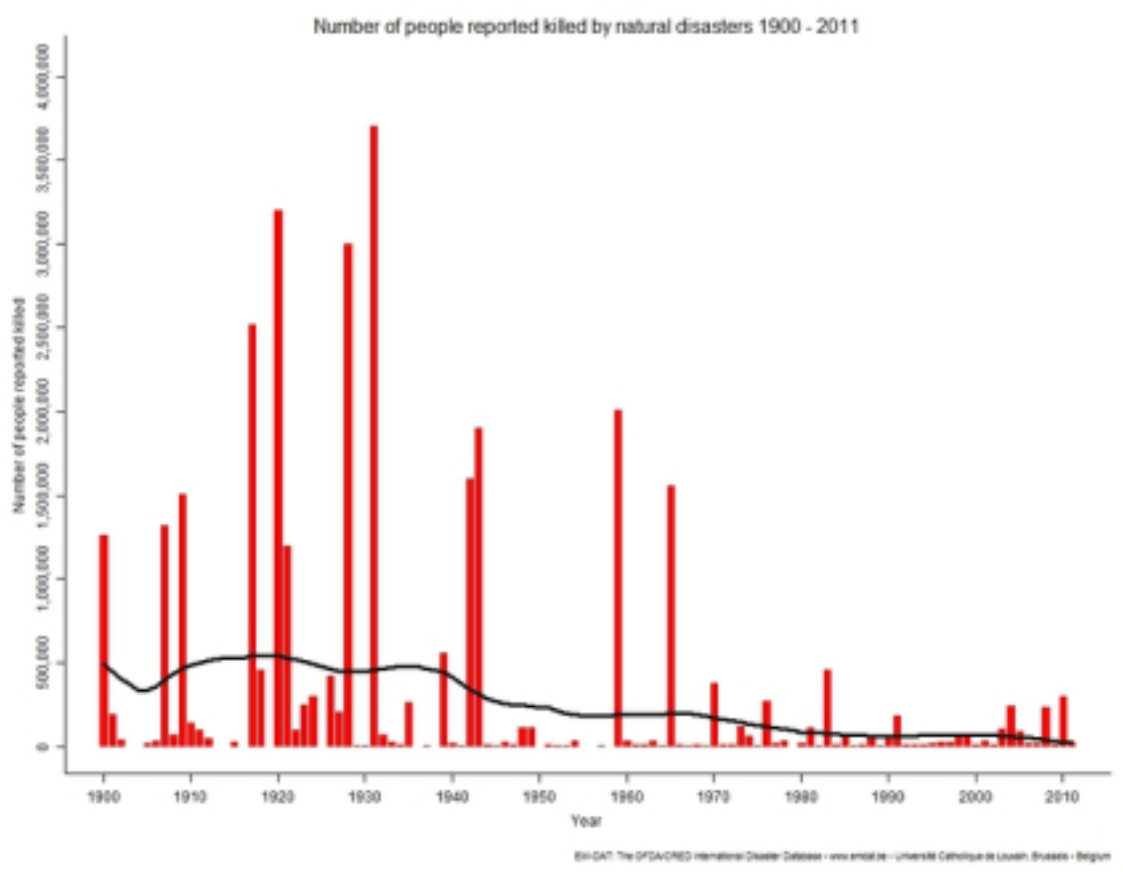

Figure 2. No. of People Reported Killed by Natural Disasters 1900-2011 


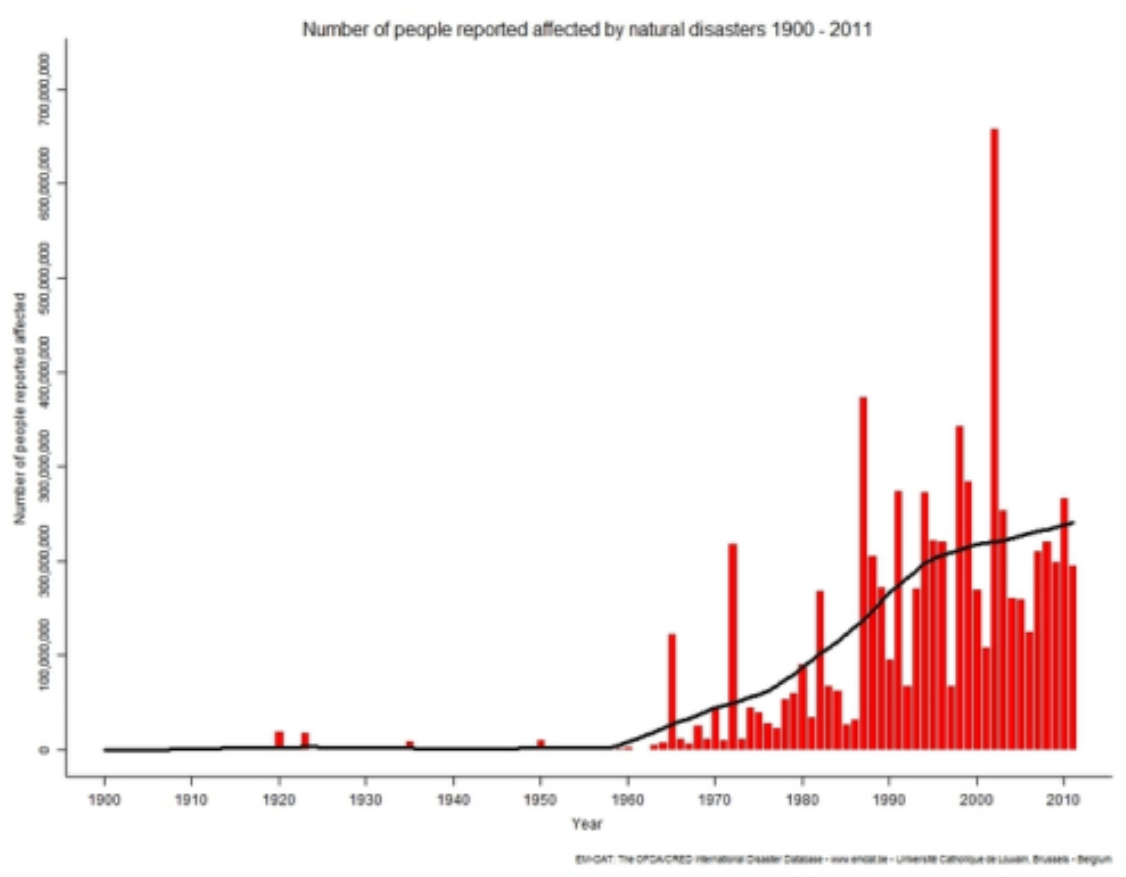

Figure 3. No. of People Reported Affected by Natural Disasters 1900-2011

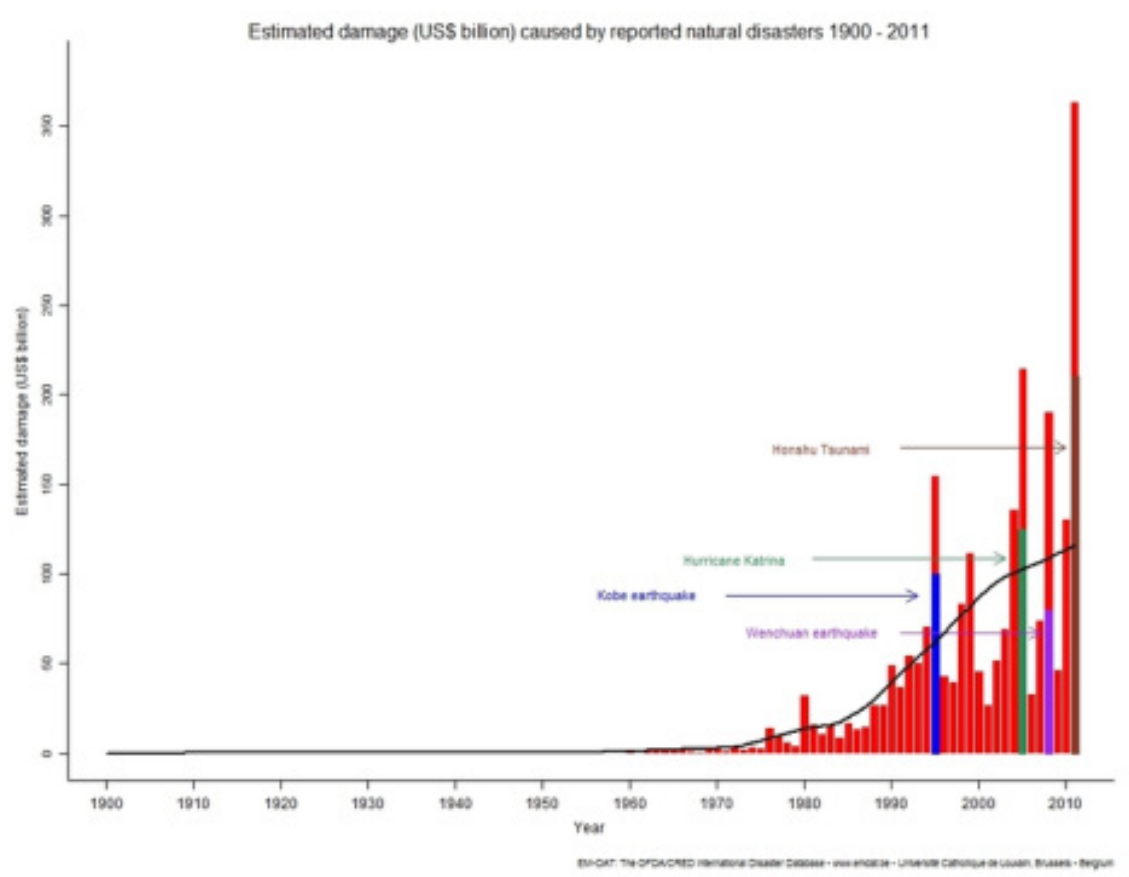

Figure. 4. Estimated Damage Caused by Reported Natural Disasters 1900-2011

A status report of Disaster Management in India (2005) clearly defined the framework, policies and procedures assigning the roles to the concerned personnel but, there is no evaluation of its implementation. Thomas and Mizushima (2005) called for 'increased professionalization of humanitarian logistics through improved personnel selection, training and education. 


\section{Objective of the Study}

This conceptual paper intends to present a clear overview of the concept of "humanitarian logistics" in general and the "challenges for human resource functions" in particular.The paper also attempts to illustrate the thrust areas of humanitarian aid in India and identify the challenges from the existing challenges. Further, the study aims to propose an empirical study for advance research.

\section{Research Methodology}

The study used a qualitative method for understanding the concept of humanitarian logistics from the review of existing literature. It also tried to identify the HR challenges of humanitarian organizations from the studies done so far. The study used secondary data from scholarly journals and research databases.

\section{Humanitarian Logistics: A Literature Review}

Exponentially increased number of disasters and continuous failure of humanitarian aid lead to increase in attention towards humanitarian logistics. The Fritz Institute of San Francisco, which worked on professionalization of humanitarian logistics, defined it as:

"The process of planning, implementing and controlling the efficient, cost-effective flow and storage of goods and materials, as well as related information, from the point of origin to the point of consumption for the purpose of alleviating the suffering of vulnerable people. The function encompasses a range of activities, including preparedness, planning, procurement, transport, warehousing, tracking and tracing, customs clearance etc.” (Thomas \&Kopczak, 2005).

Business logistics and humanitarian logistics don't differ in many characteristics. In either, it is about reacting to the situation with controlled costs (Chandes\&Pache, 2010) but in the later, the lives are at stake and the acute time-frame makes it more complicated for co-ordination between the different stakeholders. A highly unpredictable damage caused by a disaster often creates a demand, meeting which can be operationally challenging (Cassidy, 2003; Murray, 2005). Wassenhove (2006) pointed out that about $80 \%$ of expenditure of not-for-profit organizations can be classified under the broad heading of "logistics".

\section{Conceptual Framework}

The very nature of humanitarian logistics defines different types of firms (Kovacs \&Spens, 2009) providing humanitarian aid based on their response phase (Safran, 2005: Fig. 5). Some of the classifications are: Supranational aid agencies, Governmental Organizations, Big International Non-Governmental Organizations and One-man Non-Governmental Organizations. The difference in the organizational structures affects the response times of these organizations. However, the basic framework driving every humanitarian organization (Fig 6) divides the functions under three broad headings: Preparation, Response and Reconstruction (Kovacs \&Spens, 2009).

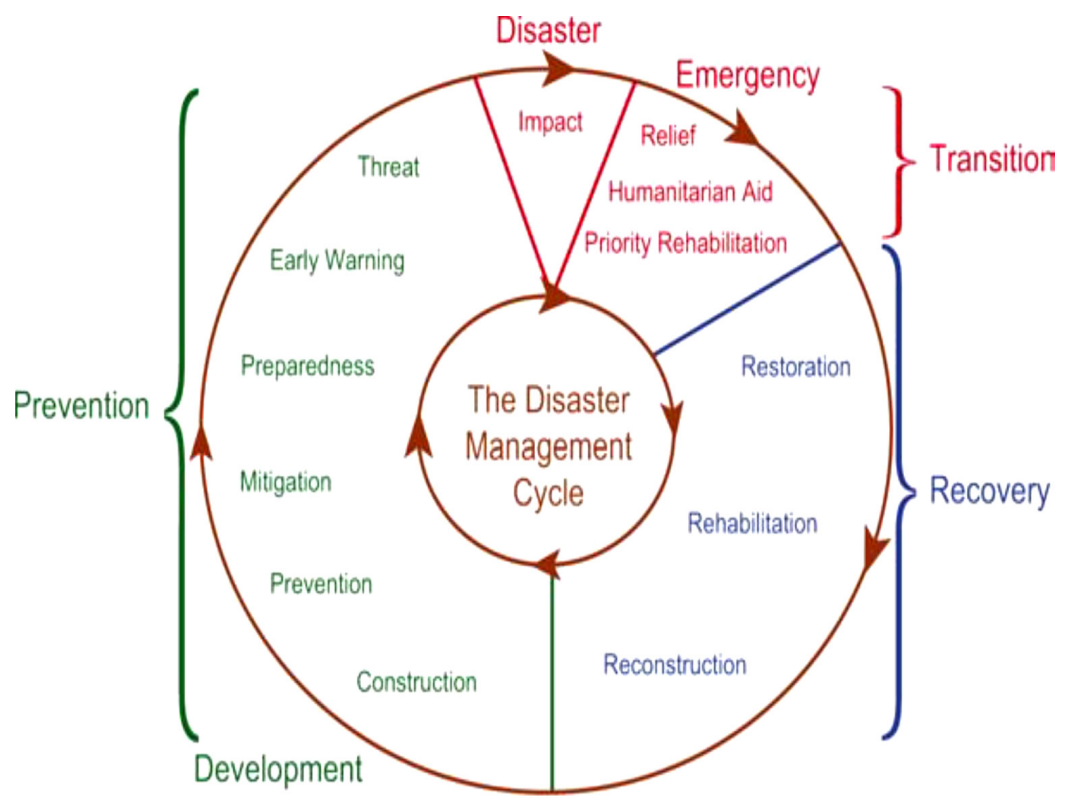

Figure. 5. Disaster Management Cycle.Source: Safran, 2005 

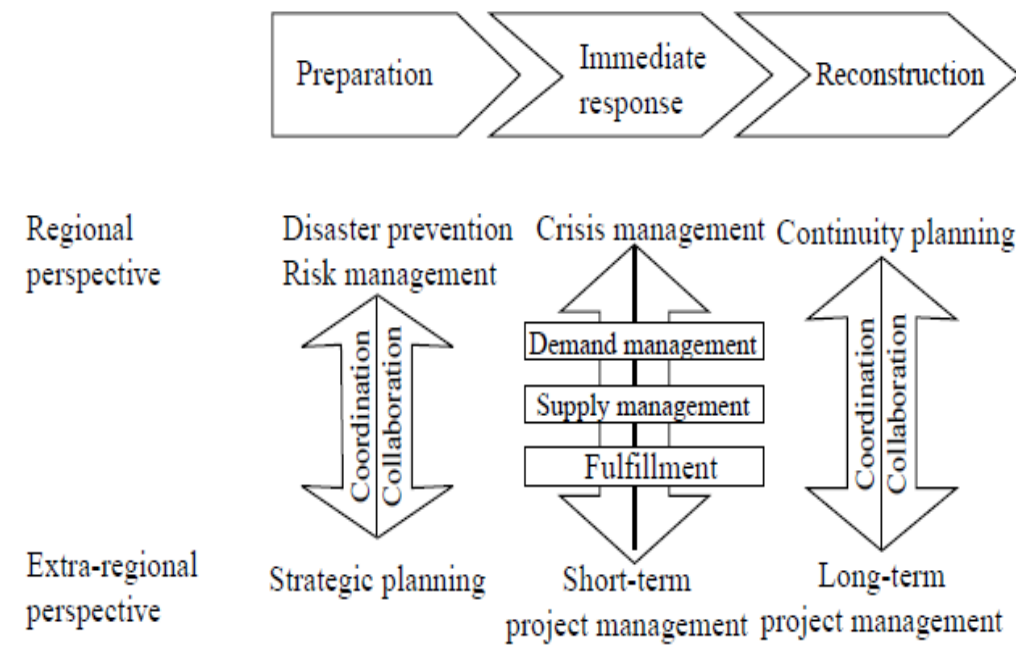

Figure 6. A Framework for Disaster Relief Logistics (Source: Kovacs \&Spens, 2009)

The role, generally, of humanitarian organizations is visible mainly during the disaster, emergency, transition and recovery phases (Fig 5) but during the Prevention phase, it seems to be often neglected (Chaikin, 2003). Murray (2005) highlights the donors also insist that their aid should directly reach the affected and not to be used for back office operations. Hence, training, preparation and prevention are generally neglected. Though logistics serves as a bridge between preparedness and response (Thomas, 2003), when it comes to implementation, only few organizations are able to achieve the results better.

Academically, the preparedness phase has received higher attention and hence, developed several decision support systems by creation and validation of realistic disaster scenarios. But all such systems assume the input data, generally the demand for goods, personnel etc. but fewer deal with immediate response phase and dynamic nature of disasters (Ozdamaret. al., 2004). However, independent to the type or intensity of the disaster, certain items like water, medicine, chlorination tablets, blankets, tents etc. (Dignan, 2005), are frequently needed by the affected. Organizations like UNICEF, continuously collect such items and develop an inventory (Dignan, 2005) while some arrange for a 'pre-purchasing' agreement with the suppliers of such items (Murray, 2005).

The very nature of a disaster requires immediate response and the uncertainty of the situation and location till the disaster makes it more complicated. The efficiency and effectiveness of the relief operation depends extremely on the logistics as it forms $80 \%$ of the total cost of operation (Van Wassehove, 2006). The number of lives saved and the volume of area reached in the acute time-frame differentiates the success and failure of the logistics system.

The reconstruction phase often receives lesser attention from many humanitarian logistics organization. Most of the time, this phase is left to the Public departments which are entrusted with the responsibility of the infrastructure development. Kovacs \&Spens (2007) highlighted that the effects of the disaster have severe consequences for a long time after the disaster.

The interesting portion of the whole process is the shift from speed to cost during the transition between the phases of disaster relief. Most of the humanitarian organizations receive and spend their funds during the response phase while the preparedness and reconstruction are generally ignored by the donors too.

\section{Strategic Planning for Human Resources}

It is terrible to think that every disaster (natural or man-made) would be alike and plan the resources accordingly. Hence, planning for standardized procedures seems obsolete in humanitarian logistics. Yet, NPOs also compete over their competitors to achieve a sustainable competitive advantage through core sets of knowledge and expertise of the personnel (Bohlander\& Snell, 2004).

\subsection{Competencies of Humanitarian Logistician}

For the effective functioning of a Humanitarian Logistics Organizations, it is understood that human resources play a key role. Hence, it is crucial to hire, develop and retain the "right" person at the "right" time in "right' numbers.

Tathamet.al (2010) illustrated the different skills and attributes that are essential in the personnel of disaster relief organizations (fig.7) in a T-Shaped model. An empirical study of strategic human resource management implications to humanitarian organizations by Hester (2005) yielded interesting results. It underlined that human capital (in terms of education and work experience) is not a better indicator of organizational performance but optimized training and minimized employee turnover can better predict performance, as suggested by Delaney \&Huselid, 1996. Hence, as also recommended by Barney (1991), training for competencies can help NPOs improve their performance. 


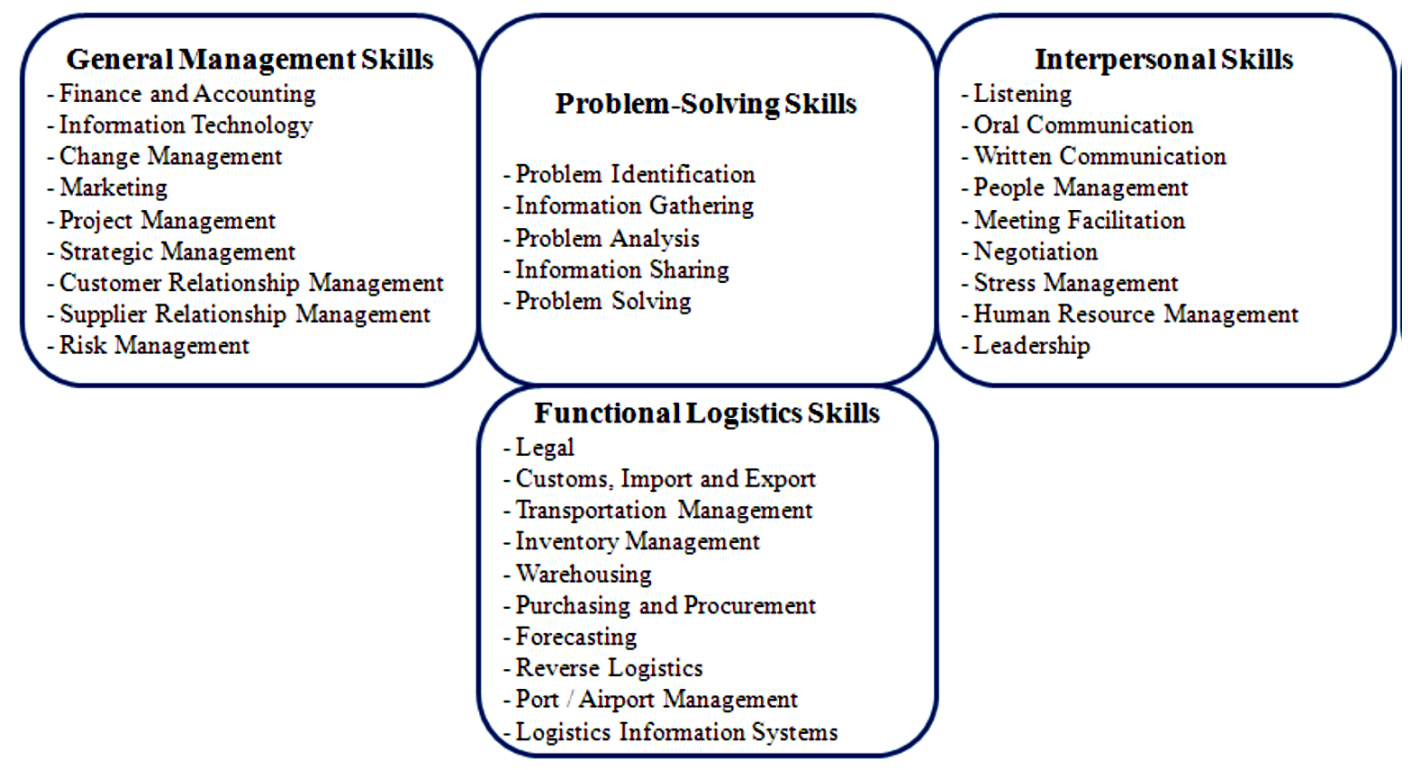

Figure 7. The T-shaped Model of Logistics Skills (Source: Tatham, Kovacs \& Larson, 2010)

With the humanitarian logistician playing a key role in the immediate response phase of a disaster, it is vital for the relief organizations to train and retain competent personnel. The study outlined that the general retention policies of the for-profit organizations might not definitely work for these people. In such an uncertain environment influencing these organizations, a high level of systematic and process driven strategic planning of human resources should be involved. Hence, the study proposes a further investigation on to understand the motivational factors of humanitarian logisticians which shall support the planning process. Also as the Hay Group Study (1999) underlines the importance of 'learning', the focus in the human resources of this sector is increasing leading to professional organizations like Fritz Institute in San Fransisco, Centre for Excellence in INSEAD etc.

\section{The Research Problem}

The T-shaped model (Tatham, Kovacs \& Larson (2010)) has been so far one of the most referred skill set for the humanitarian logisticians. However, the ground primary research to validate the model is yet to be conducted. In India the majority of relief worker base form through the defense services and paramilitary forces but a separate workforce for humanitarian aid is not focused at all. Hence, the study opens a new area for research in this space for proposing a competency model for humanitarian logisticians that is built through expert panels, focus groups' discussions, and data from both primary and secondary sources which shall be useful to define the entire HR System in every humanitarian aid organization specifically in India.

\section{Conclusions}

The study revealed that the efficiency of HL organizations often depends on the planning and right functioning of the resources in the different phases of disaster. Though the visibility of such organizations is generally high during the immediate response phase, support from the Government and donors during the preparation and reconstruction phase are equally essential. With increase in frequency of disasters, focus of the disaster relief organizations on planning, acquiring, developing and retaining the human capital is highly crucial as it is them who act with all their strength during the response phase.

The study highlighted the skills that are vital for the humanitarian logisticians and further study in this area would help us understand the HR processes involved in attaining such competencies. Also, a further study is aimed to conduct an empirical research to validate the skills and understand the specific HR processes in-use by select humanitarian-aid organizations.

\section{REFERENCES}

[1] Alexander, D. (2005), "Towards The Development Of A Standard In Emergency Planning", Disaster Prevention And Management, Volume 14 Issue 2.

[2] Barney, J. (1991), "Firm Resources And Sustained Competitive Advantage", Journal Of Management, Volume 17.

[3] Bohlander, G. \&Snell, S. (2004), "Managing Human Resources' 13th Edition, Mason, OH: South-Western College.

[4] Burke, R. J. \&Lindsay, L. (1985). "Motivating Volunteers: How The Rewards Of Unpaid Work Can Meet People's Needs",Motivation And Goal Setting. In L. Moore (Ed.), Vancouver, Canada: The Vancouver Volunteer Centre. 
[5] Cassidy, W.B. (2003), “A Logistics Lifeline”, Traffic World, October 27.

[6] Chaikin, D. (2003), "Towards Improved Logistics: Challenges And Questions For Logisticians And Managers", Forced Migration Review, Volume 18.

[7] Chandes, J., \&Paché, G. (2010). Investigating Humanitarian Logistics Issues: From Operations Management To Strategic Action.Journal Of Manufacturing Technology Management, 21(3).

[8] Chapple, K. (2012). Chapter 5. Building TheLabour Market And Human Capital. Paris: OrganisationFor Economic Cooperation And Development (OECD).

[9] Collins, C. (2000), "Strategic Human Resource Management And Knowledge-Creation Capability: Examining The Black Box Between HR And Firm Performance", Dissertation, University Of Maryland.

[10] Delaney, J. \&Huselid, M. (1996), "The Impact Of Human Resource Management Practices On Perceptions Of Organizational Performance", Academy Of Management Journal, Volume 39 Issue 4.

[11] Dignan, L. (2005), “ Tricky Currents; Tsunami Relief Is A Challenge When Supply Chains Are Blocked By Cows And Roads Don't Exist”, Baseline, Volume 1 Issue 39.

[12] Disaster Management Act, 2005, Government Of India.

[13] Gammelgaard, B. And Larson, P. (2001), "Logistics Skills And Competencies For Supply Chain Management", Journal Of Business Logistics, Vol. 22 No. 2.

[14] Gershwin, Mary C. (1996). "Workplace Learning: Reports Of Change From Supervisors And Learners", Workplace Skills: Newsletter Of Educational Partnerships In Colorado.

[15] Goulet, L. \&Frank, M. (2002), "Organizational Commitment Across Three Sectors: Public, Non-Profit And For-Profit", Public Personnel Management, Volume 31 Issue 1.

[16] GyöngyiKovács, \&Spens, K. (2009). Identifying Challenges In Humanitarian Logistics. International Journal Of Physical Distribution \&Logistics Management, 39(6).

[17] Kovacs, G \&Spens, K M (2007), "Humanitarian Logistics In Disaster Relief Operations", International Journal Of Physical Distribution And Logistics Management, Volume 37 Issue 2.

[18] Kovacs, G \&Spens, K M (2007), “Identifying Challenges In Humanitarian Logistics" International Journal Of Physical Distribution And Logistics Management, Volume 39 Issue 6.

[19] Lorenzo J. Hester (2005), “The Impact Of Strategic Human Resource Management On Organizational Performance: A Perspective Of The Resource-Based View Of The Firm", Dissertation, Nova Southeastern University.

[20] Mangan, J. And Christopher, M. (2005), "Management Development And The Supply Chain Manager Of The Future", International Journal Of Logistics Management, Vol. 16 No. 2.

[21] Montgomery, J. D (2006), "The Relationship Between Training And Retention In A Volunteer Organization", Dissertation, Auburn University, Alabama.

[22] Murray, S. (2005), "How To Deliver On The Promises: Supply Chain Logistics: Humanitarian Agencies Are
Learning Lessons From Business In Bringing Essential Supplies To Regions Hit By The Tsunami”, Financial Times, January 7.

[23] National Disaster Management Division/MHA/GOI/28/06/2 004

Http:/Www.Unisdr.Org/2005/Mdgs-Drr/National-Reports/I ndia-Report.Pdf.

[24] Pettit, S. \&Beresford, A. (2009), "Critical Success Factors In The Context Of Humanitarian Aid Supply Chains", International Journal Of Physical Distribution \&Logistics Management, Volume 39 Issue 6.

[25] Roh, S., Pettit, S.J. And Beresford, A.K.C (2008), "Humanitarian Aid Logistics: Response Depot Networks", Abstract Proceedings Of NOFOMA Conference, Helsinki, June.

[26] Safran, P. (2005), "Disaster And Emergency Policy, May 2005", Asian Development Bank, P. 33, Available At: Www.Adb.Org/Documents/Policies/Disaster_Emergency/Di saster_Emergency.Pdf.

[27] Safran, P. (2005), "Disaster And Emergency Policy, May 2005", Asian Development Bank, P. 33, Available At: Www.Adb.Org/Documents/Policies/Disaster Emergency/Di saster_Emergency.Pdf.

[28] Tatham, P., Kovacs, G. \&Larson, P. (2010), "What Skills And Attributes Are Needed By Humanitarian Logisticians-A Perspective Drawn From International Disaster Relief Agencies", PPMS 21stAnnual Conference, Vancouver, Canada.

[29] Thai, V. V., Cahoon, S., \&Tran, H. T. (2011). Skill Requirements For Logistics Professionals: Findings And Implications. Asia Pacific Journal Of Marketing And Logistics, 23(4).

[30] Thai, V. V., Cahoon, S., \&Tran, H. T. (2011). Skill Requirements For Logistics Professionals: Findings And Implications. Asia Pacific Journal Of Marketing And Logistics, 23(4).

[31] Thomas, A. (2003), “Why Logistics?”,Forced Migration Review, Volume 18.

[32] Thomas, A. And Kopczak, L. (2005), "From Logistics ToSupply Chain Management: The Path Forward In The Humanitarian Sector", Fritz Institute, San Francisco, CA.

[33] Thomas, A. And Mizushima, M. (2005), "Logistics Training: Necessity Or Luxury?",Forced Migration Review, Volume 22.

[34] Van Hoek, R., Chatham, R. And Wilding, R. (2002), "Managers In Supply Chain Management: The Critical Dimension", Supply Chain Management, Vol. 7 No. 3.

[35] Van Wassenhove, L. N. (2006) Blackett Memorial Lecture, "Humanitarian Aid Logistics: Supply Chain Management In High Gear, Journal Of Operations Research Society" Volume 57 Issue 5.

[36] Veen, A. (2004), "Disasters And Economic Damage: Macro, Meso And Micro Approaches", Disaster Prevention And Management, Volume 13 Issue 4. 